UNIVERSITY OF MASSACHUSETTS

AT AMHERST

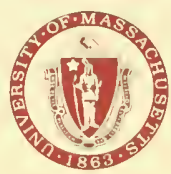

UNIVERSITY LIBRARY

Special Collections \& Rare Books
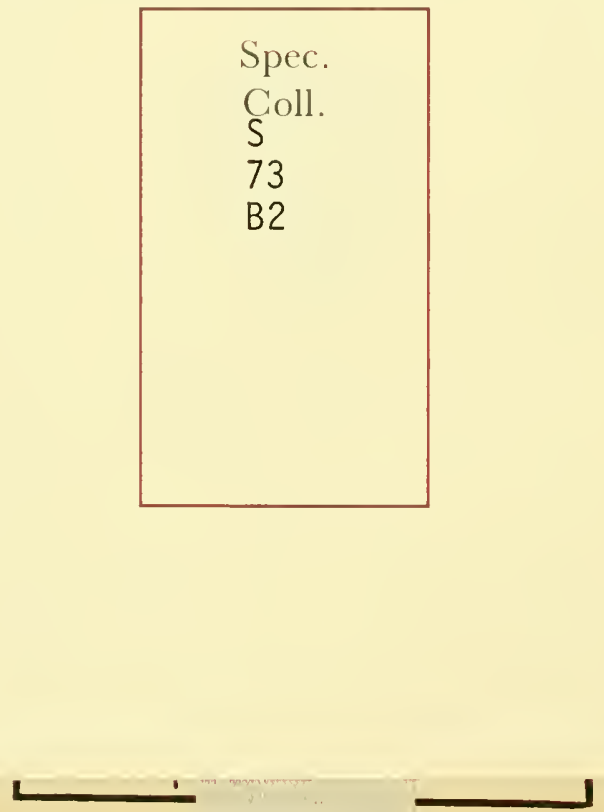




\title{
LAWS AND REGULATIONS
}

\author{
OF THE
}

MASSACHUSETTS SOCIETY.

FOR PROMOTIN G

\section{A G R I C U L T U R E. CON TAIN I N G,}

The NAires of its prefent OFFICERS and MEMBERS, LIST of PREMIUMS, \&c.

W I T H

Some interefting EXTRACTS from ForeIGN and DoMestick Publications.

BY THE TRUST E E S.

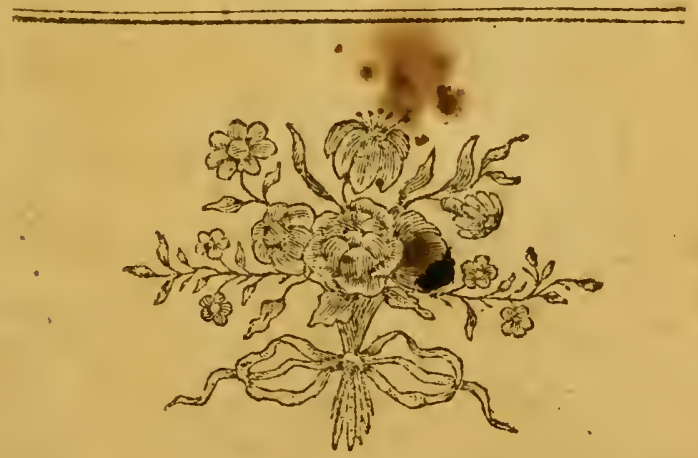

PRINTED AT DOSTON,

B ISAIAH THOMAS AND EBENEZER T. ANDREIVS。

FAUST"s STATUE. NO, 45, NEWBVRY STREET.

MDCCKCII. 
$-$

$$
\begin{aligned}
& 630.06 \\
& m 38 . l
\end{aligned}
$$

12

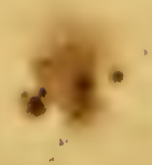

9. 


\section{TO THE PUBLICK.}

THE imperfect ftate of hufbandry in general, in this country, is too well known to require any difcurfion. This circumftance fuggefted the origin of the Maffachufetts Society for promoting Agriculture.

The farmers of this ftate, are equal, and perhaps fuperior, in their knowledge of agriculture, to their fellow citizens in any part of the Union; but we muft acknowledge, that the fcience and practice of hufbandry in fome foreign countries, are far fuperiour to our attainments. One great object of this Society will be, to obtain and publifh an account of the improvements of other countries, and to procure models of machines in which they excel. It will attend to whatever relates to. rural affairs, and efpecially to promote an increafe of the products of ourlands, fuch as the improvements of foil by tillage, manures, clearing, and draining, the cultivation of fuch graffes, and other articles, as may be moft advantageous to the farmer, and of courfe to all claffes of people, and fuch as are beft adapted to our foil and climate; the moft profitable kinds of feed, with the time and manner of fowing and cultivating them; the beft method of propagating and preferving fruit trees from infects, particularly from the canker worm; alfo, the beft method of increafing foreft trees. The feeding and management of neat cattle and theep, and the beft method of making and preferving butter and cheefe. 
To encourage the utmolt attention to thcfe objects, the Society will, from time to time, offer fuch premiums as their funds will admit. They confider agriculture in its various branches and connexions as highly interefting to all mankind. The wealth and importance of the community, is fo intimately connected with, and de. pendent on the extent and fuccels of agriculture, that every one who is defirous of advancing the happinels, profperity, and dignity of his country, its commerce, and convenient fubfifance of individuals, will lend his aid to this moft ufeful inftitut ion.

The members of this Society have no other intereft, than the benefit of the human fpecies at large. They confider themfelves members in common, of the great family, and expeet no other advantage than the fatisfaction of being beneficial to themfelves, with the reft of the community.

They therefore, in confequence of the charge they have taken on themfelves, call in the moll earnef manner, on every practical farmer, to fend to either of the Secretaries in Bofton, all the information which he poffefles on any fubject connected with agriculture. The Socicty with to obtain the modes of practice in different parts of this country, but particularly of this ftate, that they may publifh the fame; that one part may be berefited by the improvements of the other. There are many perfons in every community, who make improvements that perith with the poffeflor, merely for want of fome place where they may be perpetuated. The Society will feel obliged to every perfon for their attention and communications, even if they poffels nothing more than is generally underftood. Every correfpondent has a right to withhold his name, but if the names fhould appear, which the Society would prefer, and the communications contain nothing extraordinary, 
traordinary, they may be affured of the gratitude as well as candour of the Society.

All perfons elected honorary members, in whatever ftate or country, have a right to be prefent at the femiannual meetings, in April and October, and are invited to affint, by their communications to the Truftees, in advancing hulbandry.

This publication is defigned to inform the members, who have not attended the meetings, of the nature of the inftitution and regulations, and the publick of the general views of the Socicty, and to make the particular objects of premiums, that have been already determined on, more univerfally known.

The Society call on every perfon, who feels inclined to fuggeft any other objects for pecuniary rewards, to communicate them without referve, to either of the Secretaries, and as foon as their funds will admit, particu. lar attention will be paid to fuch communications. 



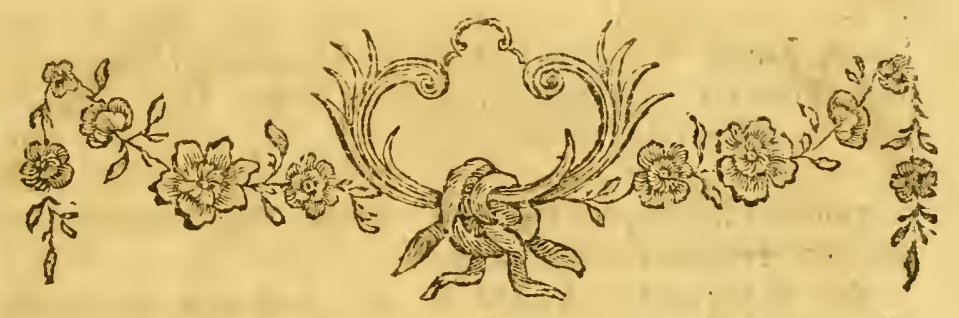

\section{LAWS AND REGULATIONS, \&c:}

\section{ACT OF INCORPORATION.}

COMMONWEALTH OF MASSACHUSETTS.

In the the year of our Lord, one thoufand feven hunnared and ninety two.

An AEt to incorporate and offablifin a Society by the name of the Massachusetts Society fur promoting Agriculture.

Whereas very great and important advantages may arife to the community, from inftituting a Society for the purpofe of promoting Agriculture, and divers perfons having petitioned to this court to be incorporated into a Society for that laudable purpofe.

Be it therefore enacted by the Senate and Houfe of Reprefentatives in General Court affembled, and by the authority of the fame, That the faid petitioners, viz. Samuel Adams, John Avery, jun. Jofeph Barrell, Martin Brimmer, Charles Bulfinch, John Codman, Edward Cutts, Aaron Dexter, Thomas Durfee, Mofes Gill, Chriftopher Gore, Benjamin Guild, Stephen Higginfon, Henry Hill, Samuel Holten, Benjamin Lincoln, John Lowell, Jonathan Mafon, Jonathan Mafon, jun. Azor Orne, Samuel Philips, Thomas Ruffel, Samuel Salinbury, David Sears, 
Sears, James Sullivan, Cotton Tufts, Charles Vaughan, and Thomas Winthrop, together with fuch others who thall become members thereof, be, and they are hereby incorporated into, and made a body politic and corporate forever, by the name of the Maffachufetts Society for promoting Agriculture.

And be it further enacted by the authority aforefaid, That the faid corporation be, and are hereby declared and made capable in law of having, holding, purchafing and taking in fee fimple, or any lefs eftate, by gift, grant, devife, or otherwife, any lands, tenements, or other eftate, real and perfonal; provided that the annual income of the faid real and perfonal eftate, fhall not exceed the fum of ten thoufand pounds, and alfo to fell, alien, devife, or difpofe of the fame eftate, real and perfonal, not ufing the fame in trade or commerce.

And be it further enalted by the authority aforefaid, That the faid corporation thall have full power and authority to make, have, and ufe a common feal, and the fame to break, alter, and renew at pleafure; that it thail be capable in law to fue and be fued, plead and be impleaded, anfwer and be anfivered unto, defend and be defended, in all courts of record, or other courts or places whatfoever, in all actions real and perfonal and mixed, and to do and execute all and fingular other matters and things, that to them fhall, and may appertain to do.

Anid be it further enacted by the authority a forefaid, That the faid corporation may maké, eftablifli and pu: in execution, fuch laws and regulations as may be neceffary to the government of faid corporation, provided the fame fhall in no cale be repugnant to the laws and conflitution of this ftate.--And for the well governing of the faid corporation, and the ordering their affairs, thcy fhall have fuch officers as they thail hereafter from time to time elect and appoirt ; and fuch officers as thall be defignated by the laws and regulations of the faid corporation for the purpole, thall be capable of exercifing fuch power for the well governing and order. ing the affairs of the faid corporation, and calling and holding fuch occafional meetings for that purpofe, as fhall be fixed and determined by the faid laws and regulations.

Ando 
Aid be it further enanted by the authority aforefard, That the end and defign of the inftitution of the faid Society is for the purpofe of promoting uleful improvements in Agriculture.

And be it furtherenaczed, That the place of holding the firft meeting of the faid Society, fhall be in the town of Bofton, and that Samuel Adams, Efq. be, and he hereby is, authorized and empowered, to fix the time tor holding the faid meeting, and to notify the fame to the members of the faid Society, by cauling the lame to be publifhed in one of the Bofton newfpapers, fourteen days before the time fixed on for holding the faid meeting.

In the House of RePRESENTATIVEs, March th $^{\text {th, }}$ 1792. This Bill having had three feveral readings, paffed to be enacted. DAVID COBB, SPEAKER.

In Senate, March 7 th, 1792 . This Bill having had two feveral readings, paffed to be enacted.

$$
\text { SAMUEL PHILLIPS, PRESIDENT. }
$$

Approved, Trae Copy, Atteft, JOHN HANCOCK.

JOHN AVERY, JUN. SECRETARY,

- A27)

\section{RULES AND REGULATIONS.}

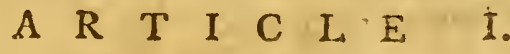 \\ THA T there thall be a Prefident, two Vice} Frefidents, a Recording Secretary, Correfponding Secretary, and Treafurer, who thall be Truitees ex officio; in addition to thefe, fix other Truftees thall be chofen from the members at large, all of whom thall coniinue in office until others are ele \&ed in their ftead.

II. ALL officers, as well as new members, thall be elected by ballot. The election thall be determined by a majority of rotes. 
11I. THERE thall be two ftated meetings of the $\mathrm{Sc}=$ ciety annually, viz. on the firft Wednefdays in April and Oetober, the fame to be held at 11 o'clock, A. M. at fuch place as the Truftees thall appoint, of which they thall give notice in one of the Bofton newfpapers, at leaft three weeks previous to faid meeting.

IV. THERE thall be an annual choice of officers, viz. at the ftated meeting in April, in the choice of whom, twenty members fhall be neceffary to make a quorum; in the tranfaction of other bufinefs, thirteen may make a quorum.

- V. IF at any meeting of the Society or of the Truftees, the Prefident and Vice Prefidents thould be abfent, the members prefent may appoint one from among them to prefide at fuch meeting.

VI. THE Prefident (or in cafe of his abfence) either of the Vice Prefidents, with the advice of the Truftees, may call a fpecial meeting of the Society ; or whenever writen application, with reafons affigned therefor, thall be made by any twelve members of the Society, to the Prefident and Truftees, they fhall call fuch meeting.

VII. THE meetings of the Truftees thall be held at fuch time and place, as they. fhall from time to.time agree upon, feven of whom, with the prefiding members, shall make a quorum for doing of bufinefs, except in the cale of election of members.

VIII. THE Truftees thall regulate all the concerns of the Society during the intervals of its meetings, propole fuch cbjects of improvement to the attention of the publick; publifi fuch communications, and offer premiums in fuch form and value as they fhall think proper, provided the premiums offered do not exceed the funds of the Society; and finall lay before the Society at each of its mectirgs, a ftatement of their proceedings, and of the communications made to them.

IX. THE candidate for election fhall firft be prod pofed by a member of the Society, and on being balloted 
ed for, if the number of votes in favour of fuch candidate fhall amount to a majority of the members prefent, fuch perfon thall be confidered as duly elećled.

$X$. THE Recording Secretary thall take minutes of all the votes and proceedings of the Society, and of the Truftees, and enter them in feparate books, and thall record all fuch communications as the Truftees may direct.

XI. THE Correfponding Secretary thall write all letters relating to the bufinefs of the Society, and anfwer all fuch letters to the Society, as the Truftees fhali direct.

XII. THE Treafurer thall receive all monies due or payable to the Society, and ail donations that may be made to it, for which he fhall give duplicate receipts, one of which fhall be lodged with the Recording Secretary, and make a fair record thereof, and from time to time, pay out fuch monies that may be in the Treafury, as he fhall have orders for from the Truftees, and fhall annually, and whenever thereto required, render a fair account of all his receipts and payments, to the Society or a committee thereof. 'The Treafurer's accounts thall be kept in dollars and cents, and he fail give bonds for the faithful difcharge of his duty, in fuch fums as the Truftees fhall direct, and with fuch fureties.

XiII. $\triangle$ COMMITTEE thall be chofen annually to audit the Treafurer's accounts, viz. at ORober meeting, and to report thereon, at the next April meeting, and the fame being accepted, thall be entered by the Recording Secretary in his books.

XIV. IN cafe of the death, refignation, incapacity, or retnoval out of the ftate of either of the Secretaries or of the Treafurer, the Truftees thall take charge of the official books, papers, and effects belonging to the offce that may be vacated, and give receipts for the fame, which books, papers, \&c. they may deliver to fome perfon, whom they tray appoint to fil up the office un. til the next mecting of the Suciety, at which time there fhall be a new choice. 
XV. The prefent members of the Society, and fuch as may, be elected previous to A pril meeting, 1793, thall for the prefent year feverally pay into the hands of the Trealurer two dollars, for raifing a fund for carrying into execution the de!igns of the inftitution; and thence afterwards two dollars annually thall be paid by each member, until otherwife ordered by the Society; the fecond year to be confidered as commencing on tho firt Wednefday in A pril, 1793.

XVI. A COMMITTEE thall be raifed from time to time, leverally to folicit and receive fubfcriptions for raifing of a fund, for encouraging the nobleft of purfuits, the agricuiture of our country, the fame to be facredly appropriated to that purpole.

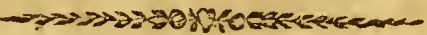

OFFICERS OF THE SOCIETY.

HON. ThOMAS RUSSELl, Efq. Prefident. HuN. TOHN LOWELL, Elq. Firft Vice Prefident. Hun. MOSES GILL, Efq. Second Vice Prefident. JOHN AVERY, JUN. Efq. Recording Secretary. OLIVER SMITH, Efq. Correfponding Secretary. AARON DEXTER, M. D. Treafurer. HON. JAMES BOWDOLN, Elq.? MARTIN BRIMMER, Elq. LOAMMI BALDWIN, Efq. CHRISTOPHER GORE, Efq. TruRees. CHARLES VALGHAN, ETq. SAMUEL PARKER, D. D.

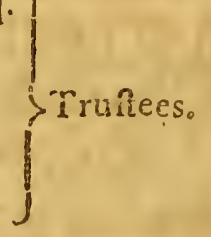

THE ADDRESS OF THE TRUSTEES.

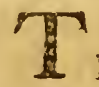
each month, free of any expenfe to the Society, for the purpole of receiving communications and promoting the purpofes of the infitution.

It is greatly to be defired that the community at large, and efpecially the members of the Society, would ein- 
gage earneftly in this bufinefs, would aid its funds, and make communication of any difcoveries they may deem ufeiul, with freedom. The officers of the Society. pledge themíclves to pay every attention in their power to the great end intended.

Among other meafures, they recommend that the members in different parts of the ftate would meet at fated times, in places convenient to themfelves, and invite the aid of others, who are defirous of forwarding improvements in agriculture; and that they would from time to time, tranfmit to the Truftees, or any officer of the Society, any information they may think ufeful.

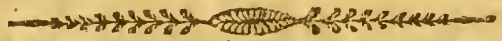

\section{I S T OF P R E M I U M.S.}

1. IO the perfon who fhall, on or before the firit day of July,.1795, give a fatisfactory natural hiftory of. the canker worm, through all its transformations; at what depth in the ground, at what diftance from the tree, and at what time they cover themfelves; at what feafon, and in what form they rife from the ground; on what part of the tree they generally depofit their eggs, and at what time the eggs become worms; a premium of 50 dollass, or a piece of plate of that value, or the Society's gold medal, * at the option of the author. If more than one fatisfactory hiftory fhould be given before the firf of July, 1795, that firf received by the Truftees will be entitled to the premium.

2. A premium of 100 dollars, to the perfon who fhall, on or before the firt day of July, 1796, difcover an effectual, and the cheapeft method of deftroying the can. ker worm, and give evidence thereof to the fatisfaction of the Trulees.

3. For the greateft quantity and beft quality of compof manure, made in one year, with the fmalleft ex-

penfe,

* The Truftees, expeding that many perfons will engage in agricultural experiments, and becume entitled to premiums, who would be more gratified, by the moft honorable teltimony of their merit in the power of the Suciety to conter, than by pecuniary rewards, have yoted, tha: a medal of gold, equal to three guineas weight, emblematically engraved, called the Society's gold medal, be given to them. 
penfe, and from a farm of the feweft acres under cuiture, and from materials common to moft farms, provided that the quantity is not lefs than two hundred tons, to be accompanied with a defcription of the barn yard, or place where made, and the mode of making the manure, a premium of 50 dollars, or the gold medal.

4. And for the next greatef quantity, not lefs than one hurdred tons, 30 dollars; claims to be prefented previous to the firtt day of May, 1795.

5. To the perfon who thall difcover a fpecies of marl, good as a makure, in fufficient quantity to become ufeful as fuch, ane exhibit a fpecimen of the fame to the Truftees; for the beft fpecimen and largef quantity difcovered, 50 dollars, or a gold medal, at the option of the claimant; claims to be prefented on or before the firft of May, 1794 .

6. To the perion who thall give the molt fatisfactory evidence of the beft kird of wheat, for this climate, and the beft mode of cultivating the fame, by actual experiment, on not lels than one acre of ground, the gold medal; claims to be prefented on or before the firft of October, $1 \% 96$.

7. For the largen quantity of fat beef, fed upon the feweft acres of ground, the quantity not being lefs than So hundred weight, a premium of 50 dollars, or the Sociely's medal; and for the next largeft quantity, not lefs than 40 liundred weight, 25 dollars, or a filver medal. $\Lambda$ particular defcription of the fize of the enclofures, mult accompany the claim, with a particular defcription alfo of the mode of fattening; claims to be made previous to the firft of October, 1795 .

8. To the perfon who thall give the beft account, from actual experiments, of the beft vegetable food, befide lay, that fhall increafe the milk of cows and ewes, during the month of February, March, and Aprii, the gold medal; claims to be prefented previous to the firft of iviay, 1795 .

g. For the largent quantily and beft quality of wool, that fhall be theared in the fame year, from the fmalleft number of theep, not lefs than one fcore, 50 dollars, or the gold medal. 
10. To the perfon who fhall within the term, of three years, cut, clear, and bring into grals, the greateft number of acres of wild land, not lefs than 20 acres; the fame to be kept clear from brufh, to be well fenced and fet off in proper divifions, 50 dollars; claims to be prefented on or before the firit day of October, $179^{6}$.

11. To the perfon who Thall produce to the Society, from actual experiments, the beft and moft expeditious method of bringing wild land to a ftate of 1 mprovement, and at the leaft expenfe, for mowing or pafturing, 50 dollars, or a gold medal; claims to be made on or before the firtt of October, $179^{6}$.

12. To the perfon who thall produce to the Society the beft and molt expeditious mode of deftroying brufh, without ploughing, 25 dollars; claims to be prefented previous to the firft of October, 1795.

13. To the perfon who thall produce the beft and moft expeditious method of making maple fugar, the manner of collecting the juice, with the leaft injury to the trees, boiling, clarifying, and completely granularing the fane, to be accompanied with a particular defcription of the fize and different kinds of veffels ufed, the cxpenfe and number of perfons required to manage them, a premiun of.7o dollars, or the gold medal.

14. It is required that the communications for which the above premiums are offered, be accompanied with proper certificates from the felectmen, magiftrates, or clergymen of the vicinity, or other vouchers to the fatisfaction of the Truftees; that they be delivered in without names, or any intimation to whom they belong; that they be feverally marked in fuch manner as each claimant thall think fit ; the claimant fending alfo a paper fealed up, having on the outfide a correfponding mark, and on the infide his name and addrefs.

$$
\begin{aligned}
& \text { By Order of the TRUSteEs. } \\
& \text { OLIVER SMITH, Cor. Sec. }
\end{aligned}
$$

May, 1793. 
COMMITTEE TO RECEIVE SUBSCRIPTIONS:

$T$

1 HE Society have appointed a committee to folicit fubfcriptions, to raife a fund, to be diftributed in premiums for the encouragement of ufeful difcoveries and improrements, viz.

THOMAS RUSSELL, Bofton。

JOHN LOWELL, Roxbury.

MOSES GILL, princeton.

AZOR ORNE, Marblehead.

COTTON TUFTS, Weymouth.

SAMUEL PHILLIPS, Andover.

JAMES WARREN, Plymouth.

THOMSON J. SKINNER, Williamfown.

TIMOTHY NEWHALL, Sturbridge.

WILLIAM BAYLIES, Dighton.

LOAMMI BALDWIN, Woburn.

JUSTIN ELY, Weft Springfield.

LEVI LINCOLN, WVorcefter.

CHARLES VAUGHAN, Bofton.

DAVID SEARS, Do.

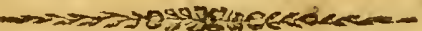

\section{N A M E $S$ of THE M E M B E R S.}

Ton. Samuel Adams, Efq.

Hon. John Adams, Elq.

tolin Avery, jun. Efa.

Hon. Finer Ames, Efq.

Nathaniel Appleton, Erq.

Dr. Nathaniel W. Appleton,

Joln Andrews, Efa.

Sofeph Allen, Efq.

Caleb Ammidown, Efq.

Jonathan Adams.

William Bodman, Efq.

Tofeph Earrell, Efq.

Martin Brimmer, Eifq.

Charles Bulfinch, Elq.

Loammi Baldwin, Efq.

Thomas Brattle, Ifq.

Satuuel Breck, Efg.

James Bowdoin, Effq.

Dr. William Baylies,

Hon. Eleazer Brooks, Erg.

John Brooks, Efq.

Hon. John Eacon, Efg̨.
Benjamin Beals, Efq.

Mofes Black,

Samuel Bars, Efg.

Hon. Samuel Baker, Efq.

Hon. Ebenezer Bridge, Ef .

Samuel Blodget, Efq.

William Billings, Eiq.

Daniel Bigclow, Efq.

Hezekiah Biffett, Efq.-honorary:

Rev. Manafieth Cutler,

John Codman, Efq.

IXon. Edward Cutts, Efq.

Hon. George Cabot, Efq̨.

Andrew Craigue,

Hon. Richard Cranch, Elq.

Samuel Cary, Efo.

Samuel Chandler,

Thomas Curbing, Efq.

Hon. Daniel Coney, Efq.

Gen. John Cutles, Erfa.

Hon. Thomas Durfee,

Dr. Aaren Dexte:,

Hon. 
Hon. Francis Dana, Efạ.

Rev. Samuel Dean,

Flias H. Derby, Efq.

Dr. Samuel Danforth,

Hon. Samuel Dexter, Efq.

Seth Davenport,

Hon. Samuel Dexter, jun. Efg.

Col. Thomas Denney,

Juftin Ely, Efq.

Hon. Timothy Edwards, Efq.

George Erving, Efq.-honorary.

Boffenger Fofter,

Hor. Samuel Fowler, Efq.

Dwight Folter, Efq.

Samuel Flagg, Elq.

Simon Frye, Efq.

Hon. Mofes Gill, Efq́.

Chriftopher Gore, Efq.

Hon. Nathaniel Gorham, Efq.

Hon. Elbridge Gerry, Efq.

David S. Greenough, Efq.

Stephen Higginfon, Efq.

Hon. Samuel Holten, Efq.

Henry Hill, Efq.

William Hull, Efq.

John Hicks,

Kev. John Homer,

Hon. William Heath, Efq́.

Dr. Ebenezer Hunt,

Samuel Henhaw, Efq.

His Excellency John Hancock, Efg.

Hon. Daniel Howard, Elq.

Thomas Hale, EfG.

Artemas How,

Hon. Jofeph Hofmer, Efq.

Hon. Jonathan Jackfon, Efa.

Charles Jarvis, Efq.

Jeonard Jarvis, Elq.

John C. Jones, Efq.

John Jenks,

Col. Joreph Jones,

Benjamin Jonyn, Efa.

Themas Ives, Efq.

Irrael Jones, Efq.

Nathan Jones, Efg.

Danforth Keyes, Efq.

Martin Kingfley, Efq.

Hon. Benjamin Lincolr. Ela.

Hon. John Lowell, Efq.

Levi Lincoln, Efq.

Capt. George Lane,

Thomas Leyate, Efq.

Jofeph Lee, Efq.

Thomas Lee, Eifq.

John Lucas, Efq.

Hon, George Leonard, Ele.

Solomon Loyell, Ifq.
Theodore Lyman, Elq:

Dr. Lettfom-honorary.

I.azarus Le Barron,

Hon. Sanuel Lyman, Efq.

William R. Lee, Efq.

John Mears,

Nelemiah Munroe,

Jonathan Mafon, Elq.

Jonathan Mafon, jun. Efg.

Abner Morgan, Éfq.

Hon. Elima May, Elq.

John Mycall, Ef́q.

Williani Martyn, Efq.

Col. John Murgan-honorary.

Rev. Dr. David McClintock-hons

Pliny Merrick, Eiq.

Hon. Timotlyy Newell, Efq.

Dr. George Orgood,

Hon. Azor Orne; Efq.

Col. Samuel Ogden-honorary.

Hon. Samuel Phillips, Efq.

Hon. Robert Treat Paine, Efq.

Charles Phelps, Efq.

Archilaus Putnam, Elq.

Rev. Dr. Samuel Palker,

Rev. Phillips Payfon,

Capt. William Putnain,

William Dandridge Peck,

Hon. John Pitts, Elq.

Samuel Pitts,

Thomas Paliner, Efa.- -honorary.

Col. Andrew Peters,

Timothy Pickering, Erq. $\rightarrow$ bonorary.

Hon. John Pickering, Eiq.

Ebentzer Peirce, Elq.

Nathaniel Paine, Efq.

Jofeph Ruffell, jun.

John Read, Efq.

Nathaniel Rulfell,

Hon. Thomas Rutfell, Efc.

Edward H. Robbins, Elo.

Benjamin Read, Efq.

Mofes Cheney Reıd, Efg.

Samuel Sal:fbury,

David Sears,

Hon. Janes Sullivan; Efq.

Hon. Increafe Sumner, Efo.

Dr. Oliver Smith,

Jonathan Simpfon,

Hon. Juhn Sprague, If́a.

Hon. Theodore Sedgwick, Efd.

Hon. Caleb Strong, Efq.

Hon. William Seaver, Lifq.

Capt. Ifazc Smith,

Hon. David Sewall, Eiq.

Hon. Willam Sheppard, Efq. 
Hon. Thomplon J. Skinner, Efq.

- Samirel Sewall, Efq.

Rev. Charles Stearns,

Esphraim Spring.

Jofiah Stearns, Elq.

Hon. Simeon Strong, Efq.

David Smead, EYq.

James Sprout, Elq.

Hon. Citton Tutts, Efq.

Ifrael Thorndike, Elq.

Dudley Atkins Tyng, Efq.

Nathaniel Tracey, Efq.

Salem Tuwne, Elq.

Bezaleel Tafis, Efq.

Ifaiah Thomas, Eif.

Charles Vaughan, Efq.

Henry Vau Schasck, Elq.

Hon. J. B. Varnum, Efq.

Capt. Phineas Upham,

Parker Varnum, Efq.
Benjamin Upton, Eía.

Hon. Oliver Wendell, Eres.

David Wood, Efq.

James Winthrop, Efq.

William Winthrop, Efq:

Thomas Winthrop,

Hon. James Warren, Efq̨.

Jofeph Ward, Efq.

Capt. Ebenezer Wales,

Dr. Joln Warren,

Dr. Thomas Williams,

Henry H. Williams,

William Wetmore, Efq.

Hon. Jonathan Warner, Efq.

Samuel Waldo,

Marfion Watton, Efq.

Dr. Benjamin Waterhoufe,

Ebenezer Waters,

Arthur Young, Efq. -honorary.

William Young.

The following Gentlemen have been added to the Committes for receiving Subfcriptions, viz.

Hon. DAVID SEWALL, Efq. York. ELIAS HASKET DERBEY, Efq. Selem. SAMUEL HENSHAW, Efq. Northampton. DUDLEY ATKINS TYNG, Efq. Tyngfoorough. HENRY VAN SCHAACK, Efq. Pittsfield.

SAMUEL WALDO, Portland.

Rev. JONATHAN HOMER, Newtown.

\section{-}

On the MANAGEMENT of the D A I R Y, particularly witis refpect to the MAKING and CURING of B UTT ER.

By J. ANDERSON, L. L. D. F. R. S. Eंc.

[Extracted from the fixth article in the fifth volume of the Letters ana Papers of the Bath Agricultural Society.]

$\mathrm{W}_{\mathrm{H}}$

Ought to be ally airy is eflablifhed, the undertakes ought to be fully acquainted with every circumftance refpecting the manufacture both of butter and cheefe ; here it is only propoled to treat of the manufacture of butter. The firf thing is to choofe cows of a proper fort; among this clafs of animals it is found by experience, 
that lome kinds give milk of a thicker confiftence and richer quality than others. In judging of the value of a cow, it ought rather to be the quantity and the quality of the cream produced from the milk in a given time, than the quantity of the milk itfelf; this is a circumftance of more importance than is generally imagined. The fmall cows of the Alderney breed afford the richelt milk hitherto known; but individual cows in every country, may be found, by a careful felection, that afford much richer milk than others; thefe therefore ought to be fearched for with care, and their breed reared with attention, as being peculiarly valuable. In comparing the milk of two cows, to judge of their refpective qualities, particular attention muft be paid to the time that has elapled fince their calving. To make the cows give abundance of milk, and of a good quality, they muft at all times have plenty of food.Grafs is the beft food yet known for this purpole, and that kind which fprings up fpontaneoufly on rich dry foils, is the beft of ali. If the cows are fo much incommoded by the heat as to be prevented from eating through the day, they ought to be taken into cool fhades for protcction; where, after allowing them a proper time to ruminate, they hould be fupplied with abundance of green food, frefh cut for the purpole, and given them by hand frequently, frefh and frefh in fmall quantities, fo as to induce them to eat it with pleafure.

Cows, if abundantly fed, fhould be milked three times a day during the whole of the fummer feafon, in the morning early, at noon, and in the evening juft before night fall. If cows are milked only twice in twenty four hours, while they have abundance of fucculent food, they will yield a much fmaller quantity of milk in the fame time, than if they be milked three times. Some attentive obfervers II have met with, think a cow in thefe circumftances, will give nearly as much milk at each time, if milked three times, as if they were milked only twice. In the choice of perfons for milking the cows, great caution thould be employed, for if all the milk be not thoroughly drawn from a cow when the is milked, a diminution of the quantity gradually takes place, and in a fhort time the cow becorres dry. In the management of a dairy, the followin necu- 
liarities refpecting miil, ought very particulariy to be at. tended to ; fome of them are, no doubt, known in part to attentive houfewives, but they have never been confidered of fo much importance as they deferve.

\section{A P H O R I S M I.}

$O F$ the milk that is drawn from any cow at one time, that which comes off at the firft is always thinner, and of a much worfe quality, than that which comes afterwaras, and the richnefs goes on, continually increafing to the very laft drop. that can be drawn from the udder at that time.

Few perfons are ignorant that milk which is taken from the cow lan of all at milking, which in this cointry is called froakings, (here frippings) is richer than the reft of the milk; but fewer Atill are aware of the greatnefs of the difproportion between the quality of the firft and the laft drawn milk from the fame cow at one milking-from feve:al accurate and important experiments it appears, that the perfon who, by bad milking of his cows, loofes but half a pirt of the laft milk that might be obtained, loofes in fact, about as much cream as would be afforded by fix or eight pints at the beginning, and loofes befides, that part of the cream, which alone can give richnefs and high flavour to his butter.

\section{A P H O R I S M II.}

IF milk be put in a difh and allowed to fland till it throws up crean, that portion which rifes firft to the furface is richer in quality and greater in quantity than what rifes in a fecond equal portion of time, and the cream that rifes in the fecond interval of time is greater in quantity and richer in quality than what rifes in a third equal space of time, and fo on, the cream decreafes in quantity and declines in quality cona. timually, as long as any rifes to the furface.

\section{A P. H O R I S M III.}

THIC $K$ milk always throws up a fmalier proportion of the cream it adually contains to the furface, than milh that is thinner, but that cream is of a richer quality; and if: water be added to that thick milk, it will afford a confederably greater quantity of cream than it would have done if allowed to remain pure: but its quality is at the fame time greally debafed.

APHORISM 


\section{A P H O R I S M IV.}

MILK, which is put into a bucket or other proper veffel, and carried in it to any confiderable diftance, fo as to be much agztaled, and in part cooled before it be put into the milk pans to fettle for cream, never throws up jo much nor fo rich cream as if the fame milk had been put into the milk pans dircedly after it was milked.

In this cale, it is believed that the lofs of cream will be in proportion. to the time that has elapfed and the agitation it has fuftained after having been drawn from the cow.

From the above facts the following corollaries feem to be clearly deducible.

1. It is of importance, that the cows thould be aiways milked as near the dairy as poffible, and it mult be of great advantage in a dairy farm, to have the principa! grafs fields as near the dairy as poffible.

2. The practice of putting the milk of all the cows of a large dairy into one velfel, as it is milked, there to remain till the whole milking be finifhed, before any part of it be put into milk pans, feems to be highly injudicious, not only on account of the lofs that is fultained by agitation and cooling, but alfo, as it prevents the owner of the dairy from diftinguifhing the good from the bad cows milk; a better practice therefore, would be, to have the milk drawn from each cow feparately, put into the creaming pans as foon as it is milked, without being mixed with any other.-Thus would the careful farmer be able, on all occafions, to obferve the particular quality of each individual cow's milk, as well as its quantity, and to know with precifion, which of his cows it was his intereft to difpofe of, and which he ought to keep and breed from.

3. If it be intended to make butter of a very fine quality, it would be advifeable in all cafes to keep the milk, that is firft drawn, feparate from that which comes laft, as it is obvious, that if this be not done, the quality of the butter will be greatly debafed, without much augmenting its quantity. It is allo obvious that the quality of the butter will be improved in proportion to the fmallnefs of the proportion of the latt drawn milk that is retained, $f_{a}$

that 
that thofe who wifh to be fingularly nice in this refpee will only retain a very fmall proportion of the laft drawn milk.

4. If the quality of the butter be the chief object attended to, it will be neceffary not only to feparate the firft from the laft drawn milk, but alfo to take nothing but the cream that is firft feparated from the beft milk, as it is this firft rifing cream alone that is of the prime quality; the remainder of the milk, which will be flill fweet, may be either employed for the purpofe of making fweet milk cheefes, or it may be allowed to fand to throw up cream for making butter of an inferiour quality.

5. From the above facts, we learn that butter of the very beft prjfble quality can only be obtained from a dairy of confiderable oxtent when judicioully managed.

6. From thefe premifes, we are led to draw a conclufion different from the opinion that is commonly entertained on this fubject, viz._- That it feems probable that the very beft butter can only be with economy made in thofe dairies where the manufacture of cheefe is the principal obje\&t.

As but few perions would be willing to purchafe the very beft buiter at a price to indemnify the farmer for his trouble, I am fatisfied from experience and attentive obfervation, that if in general about the firft drawn half of the milk be feparated at each milking, and the remainder only be fet up for producing cream, and if that milk be allowed to ftand to throw up the whole of its cream, even till it begins fenfibly to tafte fourifh, and if that cream be afterwards carefully managed, the butter thus obtaired will be of a quality greatly fuperiour to what can ufually be obtained at market, and its quantity not confiderably lefs than if the whole of the milk had been treated alike.

No dairy can be managed with profit, unlefs a place properly adapted for keeping the milk, and for carrying on the different operations of the dairy, be firft provided.* The neceffary requifites of a good milk houfe are, that it be cool in fummer, and warm in the wirter, fo as to preferve a temperature neariy the fame throughout the whole year,

- The author here gives a very farticular defcription of the bef contrived milk houfe or dairy. 
year, and that it be dry, fo as to admit of being kept clean and fweet at all times.

From the trials I have made, I have reafon to believe that when the heat is from fifty to fifty five degrees on Farenheit's thermometer, the feparation of the cream from the milk, which is the molt important operation of the dairy, goes forward with the greateft regularity. When the heat exceeds fixty degrees, the operations become difficult and dangerous, and when it falls below the fortieth degree, they can fcarcely be carried forward with any desree of economy, or propriety.

In winter, hould the cold become too great, it might be occalionally difpelled, by placing a barrel full of hot water clofely bunged up, upon the table, to remain till cooled. This I prefer to any kind of chaffing difh with burning embers.

The utenfils of the dairy, muft in general be made of wood. As the acid of milk readily diffolves lead, with which the common earthen veffels are glazed, fuch veffels fhould be banifhed from the dairy.

The creaming difhes (for fo I call the veffels in which the milk is placed for throwing up the cream) when properly cleaned, fweet and cool, are to be filled with the milk as foon after it is drawn from the cow as poffible, having been firft ftrained carefully through a clofe ftrainer.

Thefe difhes fhould never exceed three inches in depth, whatever be their other dimenfions. As foon as they are filled, they are to be placed on the fhelves in the milk houfe, perfectly undifturbed, till it be judged expedient to feparate the cream from them.

In a moderately warm temperature of the air, if very fine butter be intended, it thould not be allowed to ftand more than fix or eight hours; for ordinary good butter, it may fafely ftand ten or twelve, or more.

It is of great importance to the fuccel's of the dairy, that the fkimming be well performed, for if any part of the cream be left, the quantity of the butter will be diminifhed; and if any part of the milk be taken, its quality will be de. bafed.*

\section{When}

- The cream thould be feparated from the edges of the dith, by means of an ivory bladed knife, then carefully drawn towards one fide by a Limning dih, and then taken off with great nicety. 
When the cream is obtained, it ought immediately to be put into a veffel by itfelf, there to be kept till a proper quantity be collected for being made into butter. And no veffel can be better adapted to that purpofe than a firm neat made wooden barrel, in fize proportioned to the dairy, open at one end, with a lid exactly fitted to clofe it. In the under part of this veffel, clofe to the bottom, fhould be placed a cock and fpigot, for drawing off any thin ferous part of the milk that may chance to be there generated; for if this is allowed to remain, it injures the cream, and greatly diminifhes the richnefs of the quality of the butter ; the infide of the opening flould be covered with a bit of gauze netting, to keep back the cream while the ferum is allowed to pafs, and the barrel fhould be inclined a little forward, to allow the whole to run off.

The feparation of butter from cream, only takes place after the cream has attained a certain degree of acidity: The judicious farmer will therefore allow his cream to remain in the veffel until it has acquired that proper degree of acidity that fits it for being made into butter with great eafe, by a very moderate degree of agitation; and by which procefs only, very fine butter ever can be obtained. How long cream may be thus kept in our climate, without rendering the butter made from it of a bad quality, I cannot fay; but it may be kept good for a much longer time than is generally fufpected, even a great many weeks.-It is certain that cream which has been kept three or four days in fummer is in an excellent condition for being made into butter; from three day's to feven, may in general be found to be the beft time for keeping cream before churning.

I prefer the old fafhioned upright churn, having a long: handle, with a foot to it perforated with holes, as it admits of being better cleaned, and of having the butter more eafily feparated from the milk than any others.

Where the cream has been duly prepared, the procels of butter making is very eafy; there is however more nicety required than moft perfons feem to be aware of; a few hafty, irregular frokes, may render the butter of fcarcely any value, which, but for this circumftance, would have been of the fineft quality. The butter when made, muft 
be immediately feparated from the miik, and being put into a clean dith, the infide of which, if of wood, fhould be well rubbed with common talt. The butter thould be prefled and worked with a flat wooden ladle, having a flort handle, fo as to force out all the milk that was lodged in the cavitics of the mafs. The beating up of the butter by the hand is an indelicate and barbarous practice. If the milk be not entirely taken away, the butter will infallibly fpoil in a thost time, and if it be much wafhed, it will become tough and gluey. Some perfons employ cold water in this operation; but this practice is not only ufelefs, but alfo pernicious, becaure the quality of the butter is thus debaled in an aflonifhing manner. In every part of the foregoing procels it is of the utmoft importance, that the velfels and every thing elle about the dairy, be kept perfcelly fireet and clean.

Wooden veflels are the molt proper for containing falted butter. Oak is the beft wood for the boitom and faves. Broad fplit hoops are to be preferred to all others.

Iron hoops thould be rejected, as the ruft of them will in time fint through the wood, and injure the colour of the butter. To feafon a ncw veffel for the reception of falted butter, requires great care : It thould be filled frequently with fcalding water, allowing it to remain till it llowly cools. After the butter has been cleaned from the milk, as before directed, it is ready for being falted. Let the veffel be rendered as slean and as fwect as poffible, and be rubbed all over in the infide with common falt; and let a little melted butter be run into the cavity betwecn the bottom and the fides at their joining, fo as to fill it, and make it every where flufh with the bottom and fides: It is then fit to receive the butter. Common falt is almolt the only fubftance hitherto employed for preferving butter. I have found by experience that the following compofition is in many refpects preferabie to it, as it not only preferves the butter more effectually from any taint of rancidity, but makes it look better and tafte freeter and more marrowy, than if the fame butter bad been cured with common falt alone. The compofition is as follows: 
Take of fugar one part, of nitre (fait petre) one part, and of the beft Spanifh great falt, two parts; beat the whole into a fine powder, mix them well together, and put them by for ufe.

Of this compofition, one ounce fhould be put to every fixteen ounces of butter: Mix this falt thoroughly with the butter; as foon as it has been freed from the milk, and put it, without lofs of time, into the veffel prepared to receive it, preffing it fo clofe as to have no air holes, or any kind of cavities within it ; mooth the furface, and if you expect it will be more than two days before you add more, cover it clofe up with a piece of clean linen, and over that a piece of fine linen that has been dipped in melted butter, that is exactly fitted to the edges of the veffel all round, fo as to exclude the air as much-as poffible, without the afiffance of any watery brine. When more butter is to be added, remove the coverings, and let the butter be ap. piled clofe above the former, prefling it down, and fmoothing it as before, and fo on till the veffel is full. When full, let the two covers be fpread over it with the greateft care, and let a little melted butter be poured all round the edges, fo as to fill up every cranny, and effectually cxclude the air. A little falt may then be flrewed over the whole, and the cover firmly fixed down, to remain clofely fhut till opened for ufc. If this be carefully done, the butter may be kept perfectly lound in this climate for many years.*

It muft be remarked that butter cured in this manner, does not tafto well till it has food at leaft a fortnight after being falted. After that period is elapfed, it eats with a rich marrowy tafte that no other butter ever acquires. Butter thus cured, will go well to the Eaft or Weft Indies.

Butter, in its natural ftate, contains a confiderable proportion of mucous matter, which is more highly putrefcible than

* The Epping butter is called the bett in Englana. The farmers make ufe of a very innocent colouring matter for their winter and early fpring butter, which is the juice of carrots. They take clean and frefin carrots, and grate them fine, and fqueeze out the juice through a coarfe cloth, and mix it with their cream. This gives their butter as fine an appearance as ihe. beft June butter, without conmunicating any tafte or Axv our. 
than the pure oily parts of the butter. When it is intend. ed to be expofed to the heat of warm climates, it ought to be freed from that mucilage before it be cured and packed up. To dothis, let it be put into a veffel of a proper thape, which fhould be immerfed in another containing water. Let the water be gradually heated till the butter be tho. roughly melted: Let it continue in that ftate for fome time, and allow it to fettle: The mucous part will fall to the bottom, and the pure oil fwim at top. When, it cools, it becomes opaque and paler than the original butter, and of a firmer confiftence. When this refined butter is become a little Aiff, and while it is fill fomewhat foft, the pure part fhould be feparated from the diregs, and then falied and packed up in the fame way as is before directed. $f$

Thofe who wifh to fee the fubject mo:e fully treated, are referred to the original.

An Account of the Manner of Making CHEESE in ENGLAND.

[By Mr. Twamex.]

IN this fecond great object of the dairy, the fame precaution as with regard to the butter, is neceffary, viz. The cows ought not to be driven violently before milking, and every utenfil muft be kept equally clean.

The mot common defects of cheefe are, its anpearing, when cut, full of fmall holes, called eyes; its puffing up, cracking, and pouring out a quantity of thin whey ; becoming afterwards rotten and full of maggots in thofe places where the whey appeared. All thefe difficulties proceed from a fubftance called fip curd, a kind of half coagulum, incapable of a thorough union with the true curd, and which, when broken into fmall bits, produces eyes, but if in larger pieces, occafions thofe rents and cracks in the cheefe already mentioned; for though this kind of curd 
curd retains its coagulated nature for fome time, it always; fooner or later, diffolves into a ferous liquor. This kind of curd may be produced by ufing the milk too hot, by bad runnet, or by not allowing the curd a proper time to form. The firtt may be remedied by the ufe of cold water. The fecond, by good runnet, a knowledge of which can only be acquired by long practice. The only rule that can be given for its preparation is, to take out the ftomach of a calf, rince it in cold water, and rub it well with falt and dry it. It may be ufed immediately on drying, though it is confidered beft after it is a year old. The bef method of making the runnet is, to take one gallon of pure fpring water and boil it; then make it into brine with clean falt, futficiently frong to bear an egg; let it cool to about blood heat. Two of the fkins (or what are commonly in this country called runnet bags) muft be put into the bine, either cut in pieces, or whole, as is moft convenient ; they muit fteep twenty four hours; after which, it is fit for ufe. About a tea cup of a middling fize, of the liquor, will be fufficient for the milk of ten cows.

In making cheefe, fuppofing the runnet of a good quality, the following particulars muft be obferved.

1. The proper degree of heat: 'This ought to be what is called milk warm, which is confiderably below the warmth of milk taken from the cow. If too hot, it may Be reduced by cold water, without any injury to the cheefe.

2. The time allowed for the runnet to take effect : This ought never to be lefs than one hour and a half.

3. After having the curd firmly formed at the bottom of the tub, the whey muft be taken away, and the curd mutt ftand to drain one quarter of an hour.

- If any pieces of flip curd are fornd fwimming in the whey, they flould be poured off with it, rather than be admitted into the cheefe. Some dairy. women allow their curd to fand two hours, to obtain a firmnels that will require no breaking; but the beft method is to break it thoroughly, for the cheefe is lefs apt to be hard.

4. The beft method to prevent checfe from heaving, is to aroid making the runnet too ftrong, 10 talke care that 
it be vcry clean, and by no means the leaft tainted, to be certain the curd is fully formed, which is known by the blue colour of the whey, and by no means to fir it till the air has had time to efcape.

5. The beft method to prevent the cracking of cheeles, is to falt them in the milk, or after the cheefe is formed, which may be done with much more certainty than in the curd, which is a bad method.

6. Dry cracks in cheefe are frequently produced by keeping curd from one meal to another, by which means the firft becomes too dry and hard, ever, without great attention, to mix intimately with the fecond.

7. Curdly, or what is commonly called wrinkie coated cheefe, is always caufed by four milk. Cheefe made of cold milk is apt to be hard and fly before the knife. If the weather is cold, cheefe thould be kept warm, particularly when firft made.

8. Slip coat, or foft cheefe, is made entirely of llip curd, and will diffolve into a kind of creamy liquor, which is fufficient proot of the nature of this kind of curd, as already mentioned. It is generally computed, that as much milk is required to make one pound of butter, as two pounds of cheefe.

It is remarked by dealers in cheefe, as well as other perfons, that much the greateft part of the people that eat cheefe have no idea how it is produced. They finding the beft cheefe of a yellow colour, naturaily conclude that cheefe of a pale colour muft be made of inferionr or fkimmed milk, whereas the colour is artificial. The principal ingredient uled for colouring cheefe is the beft Spanith annatto (or what is commonly called in this country, otter) which gives cheele the beautiful colour of the ben fpring butter, without injuring the tafte or quality in any degree. The beft method of ufing it is, to take a piece and dip it into a bowl of milk, and wath off from the piece fufficient to give the milk a deep colour. Then mix the coloured milk with the milk prepared for the cheefe, before either runnet, or falt is put in. If enough annatto has been ufed, the whole milk will have a pale orange colour, which will be much increafed after the cheefe is made. 
Fune, 1793 .

To the Corresponding Secretary of the MassaCHusetts Agricultural SOCrety.

Sir,

THE following obfervations were drawn up at the requeft of a gentleman for his own ufe. If the Agricultural Society fhould think that the contents afford any ufeful hints, If hall be gratified with having contributed fomething towards the improvement of one branch of that art, which is the moft independent and one of the moft honour able purfuits of man.

I do not fend it to you from an opinion that I have the beft information upon the fubject, but that, by a communication of each ones experience, improvement goes forward with rapidity.

I am, Sir,

Your moft obcdient Servant, ALEXIS.

To Mr.

SI R, .

A GREEABLE to your requen, I have collected the following obfervations upon the method of making cheefe. They are what arofe during an experience of but two years. The intention was to have reduced this ufeful part of rural economy to a regular fyftem, which in this country is left to the operation of chance. This fheet contains but little originality in the principles of this art; they were taken from treatifes written in England. If any merit is due, it is for the attention with which thefe obfervations were purfued, to afcertain the effential parts of thefe treatifes. This art appears fo fimple, that every country woman would be offended at being thought ignorant of it; yet a few rules may be collected that require to be obferved with almoft a chymical exactnefs. They know that runnet will make a curd: A piece is therefore cut off at hazard and thrown into the milk. If too fmall a piece is put in, the curd comes very imperfeetly, producing what is called flip curd. This is very foft, and the curd thus 
thus made, is what is moit frequentiy foid for cream cheefe. In breaking up the curd, or prelling, this is chiefly fqueezed out. That which remains is one caule of eyes in cheefe. The fatteft part of the milk is molt dificicult to coagulate, and it is found, that adding more runnet will not perfect the curd, when in this tate; the cheefe is of courfe impoverifhed, when the curd comes imperfectly. But the moft frequent errour is putting too much runnet, which incvitably gives the cheefe a Irong pungent tafte and lmell. It occafions that puffing in cheefe which is called hove chee $\int e$, and being pierced with a knife, will emit a very fetid fmell. It is a degree of putrefaction arifing from a fermentation caufed by the runnet; a fufficient evidence that the cheefe can never be good, and is invariably full of eyes. Another caufe of bad cheefe is bad runnet; and whoever has feen many of our country kitchens, will wonder that they ever have good cheefe, owing to the very filthy manner of keeping the fkins, being either impreg. nated with fmoak, or tainted with flies, and expofed to cvery difagreeable efluvia that may furround it. To obviate thele difficulties, the following is the manner that the runnet was prepared in my dairy. Take the fkin, or runnet $\mathrm{bdg}$, as foon as the calf is killed; let it be carefully cleaned by hand without touching water; let it then be put into a brine fo frong that it will diflolve no more falt; of this brine three pints will fuffice for a fkin; let it be teeped in it $3^{6}$ hours or thereabouts; it may then be taken out of the liquor, put into clean bottles and corked; it will keep a year, perhaps longer; the fkin may then be drawn over a bow, falted and dried as.ufual; in two or three months, if your liquor fhould fail you, it may be fteeped again. It is faid to acquire new ftrength, but not fo much as at firf ; perhaps the virtue is not wholly extracted by the firft fteeping, and that it will not yield it all to three pints of water. This fecond operation will, however, anlwer as good a purpofe as the firf, ufing two or three fkins in.. ftead of one. Let one general obfervation be made, that throughout the whole bufinels of darying, the greateft attention mult be paid to the cleaniinefs and fweetnefs of the veffels ufed, and in the dairy room; and in fome inftanc- 
es it may not be unneceffary to recommend it to the dairy woman in her own perfon. In cheefe of one meal, ihe milk fhould be kept as riear as polfible to its natural heat, till the unnet is put in. 1 tind thrce ica fpoons full to a gallon of milk to be the average quantity required to $\mathrm{co}$ agulate it; but this liquor fhould always be tried, to afcertain its nrength. The objed is to find the fmalleft quantity that will bring the curd properly, as more than that will injure the cheefe. You will percejve that it is convenient to make a large quantity of this liquor at a time, or making it at diffurent times in the fpring, when you begin to make checfe, which is feldom till all the calves are killed, let it be mixed and then tried, after which there is no trouble with the runnet; and you may be certain that whatever other defed the checle may have, it will not be frong, or hore; this is folely owing to the too great quantity or bad quality of the runnct. Míy checte tub being made of the lame dianctre at the top and bottom, 1 found its contents in gallons, and made a guaging rod, marking on the depth of the tub, and then lubdividing that depth by the rumber of gallons the tub conained. By puting the rod into the tub, was readily feen the gallons of milk in it. Thetubitfelf might be thus graduated; when you would make fervants follow rules, it is necefiary that they fhould be attended with as little trouble as porfiBie. Having put in the runnet, the milk flould not be fifffered to cool too joon, as the curd fhould be fenfinly warm when broke up and put into a hoop, otherwile the cheefe will be in flakes when cut, the curd not uniting when cold. The curd muft not be difurbed in the tub, till it cleaves fron the fides and begins to fettle. It may then be cut through chiquervife and fuffered to fettle fill more; with a proper tcmperature of air it will begin to fettle in half an hour from the time of fettling the milk; cold weather retards it and may defeat it ; if the curd is too long in coming, the cream begins to rife and is loft to the cheefe; it fhould therefore be guarded againft. There rifes upon the whey, when the curd lettles, a thin fkim, which fhould be carefully removed bcfore the curd is taken out, left it fhould mig with the curd. As it is of a more fixed nature than 
the whey, it will not all fqueeze out, nor will it blend with the curd, and where a particle remains there will be an eye. The curd, being well drained of the whey, by breaking it up fine by hand, is to be falted. This is an important part, and of which I am not fo well informed as I wifh to be. The fuccefs of experiments with falt can only be determined by the tafte, and this cannot always be done, when the cheefe is fo!d. Salt ciffers greatly in ftrength and quality, as is well known to fifhermen and packers of beef. In I reland the beef is firf ftrongly rubbed with blond falt, which is mild and penetrating. It is then paffed to another hand, who ufes a mixture of blond and bay falt, which is hat th and drying, hardening the provifions. From this confideration of the different effects of falt, it may be concluded that bay falt. is not adapted to cheefe. 1 alfo took bay falt and cliffolved it, and then boiled it down; the objectionable parts fly off; and the more violent the ebullition, the finer will be the grain, which indicates its ftrength, the large grain being the ftrongeft. I liked the falt thus obtained, the grain being as fine as well ground meal. . Some of my beft cheefes were made with this falt and the ruantity ufed was one tea cup heaped, to fix gallons of milk. This proportion is liable to errour, as milk will yield more or lefs card according to the feafon or quality of the grafs; and let it be remembered that cows thould never be drove hard, efpecially juft before milking. If the common blond falt is ufed, it fhould be reduced firier by pounding, that it may more intimately blend with the curd.--The curd baing prepared for the prefs, it appears to me proper that every heterogeneous fubttance fhould inmediately be preffed out. For this purpofe my fint pref's was powerful, being a lever eight feet long, one end fixed by a pin between two ftumps let in a bench ; near thefe fumps, was placed the cheefe ; the other end of the lever was loaded with abont two hundred weight of ftones; at the other end of the bench were fixed two ftumps higher than thole firt mentioned, which are about fix inches higher under the lever than the cheefe hoops; the other ftumps have a crols piece on the top to reft another lever, which is hooked to the end of the firft to raife it. The cheefe being tended as ufual in this prefs, where it re$F_{1}$

mained 
mained twenty four hours, was moved to another bench containing four divifions; being each feparate preffes of no more weight than was immediately laid upon them, about two hundred weight. The cheefe when taken from the firlt prefs, was put into prefs at one end of this fecond bench, and remained in each twenty four hours, moving along every day till arrived at the other end. I fuppofe three days preffing on this fecond bench, fufficient for a cheefe of twenty five pounds. It was then car'ried to the cheefe room. Screw preffes are objectionable, as the preffure does not follow the cheefe as it fettles. My farm houfe was fortunately fhaded by trees; but the better to guard againft the fun, I had Venetian fhades made for the windows, of clapboards painted green, which were cheap and handiome. I alfo had made flender frames, over which catgut was ftretched of a texture fine enough to prevent the entrance of flies. When the windows were opened thefe frames were put in. The cheeferoom thould be expofed. on every fide except the fouth, and one or more windows in each fide. Attention is much required to regulate the temperature of the air; ftrong wind admilted will dry the cheefe too faft, and make it crack; to prevent this, it is cuftomary with us, to rub the cheefe with butter; in England they wafh it with the new whey, and no butter is ufed; this laft method I did not try. In hot fultry weather cheefe will fpread. This thould be prevented by bandages of tow cloth, or by putting them into cheefe hoops. The expenfe of this extraordinary number of hoops is not great: Onc cheefe faved, will pay for ten hoops, and they laft many years. They will feldom fpread after they have beer made a month. In wet weather it is advifeable to burn a little charcoal in the chimney of the cheefe room. The quantity of green cheefe obtained from milk, was from twenty three pounds to twenty five pounds, from twenty gallons. I have got twenty feven and three quarters from eighteen gallons. They feldom loft in drying more than two and a half pounds, in a cheefe of twenty five pounds weighed green from the prefs. If it is required to have the cheele of a Gloucefter colour, take Spanilh anatto, rub a lump in a faucer with milk; a little experience will teach the quantily necefrary for a cleefe; then mix it with 
thie reft of the mills, when it is fet for cheefe. One ounce will colour four or five hundred pounds, and it is bought of the apothecaries. It is perfectly innocent, and I thought that the cheefe coloured with it, was higher flavoured: This might have been owing to other caufes. To have a good dairy, it mut be a particular bufinefs, and not attended only at convenient intervals from other work, as a fecondary objcet, nor fhouid a drop of cream be taken from milk appropriated for cheefe. This muft be inviolably obferved. I think that large cheefes generally prove better than fmall ones; and for this realon thould not wifh to make a cheefe lefs than twenty five pounds. But if the number of cows is not fufficient to make a cheefe of one meal, the oid milk hould be very well mixed with the cream that has rifen, and then put into a large brafs ketthe to warm over coals free from fmoke, the milk being frequently firred to prevent the bottom of the milk becoming too hot before the top is fufficiently warmed, which will be the cafe without attention. It fhould be brought as near as poffible to its natura! heat. To fave trouble our women heat a part very hot, then mix it with the cold; but I have no doubt that this injures the cheefe. Putting the milk into deep veffels, and covering them in a damp fituation, will prevent the cream from rifing fo much as it otherwife would.

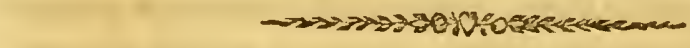

[From Letiers and Papers on Acricuzture, publithed at HALLYSAX.]

To the Secretary of the Agricultural Society, at Halifax.

THE intention of the Society being fo obvioufly of the firt importance to this country, I am induced to requeft that the following oblervations may be coinmusicated to the next meeting. 
Every day's experience evinces that our foil is good, yer, fuch is the coldnefs of the climate, that when land has been improved three or four years without manure, it grows moffy, and afterwards produces but little: There are few countries, therefore, where the article of manure can bs more profitably attended to, becaufe, when well prepared, it not only replenifies the earth with food for vegetables, but by its warmth counterbalances the coldncls of the cli.mate. As what has been written on this fubject is in the hands of but few, I have endeavoured to bring together the opinions of the mot modern authors, which from my own experierce I can recommend to the practice of the farmers in this country, rcuarking at the fame time, upon the improper ufe which too many make of their dung. Lime, Marl, Plaifter of Paris, \&c. \&c. are good, and fome of them perhaps the beft of manures: But it is not in cvery one's power to procure them, efpecially in fuch quantities as are neceffary for the farmer: But a Compost is within the reach of every perfon, and almoit in any quantities, and which no prudent perfon, upon knowing its ufefulnefs, will ever be without.

There is perhaps no one practice in hufbandry more injudicious than that of taking new dung from the yard, in the fpring, and ufing it as a manure for potatoes, ipread over the ground, or in any other way whatever, as it introduces grais, weeds, and noxious plants, which more than balances any little benefit that it can poffibly do as a manure when ufed in that unprepared nate.

When new dung lies in large heaps it foon grows very hot, and a violent putrid fermentation comes on, which melts the whole into one common mals, reverfing what took place in regetation, bringing that matter which has been the fubfance of formcr vegetables into fuch a ftate, that it will become the food for fucceeding vegetables : But when it is put in fmall quantities in the hills of potatoes, or fpread on the ground and plowed in, cven if it had begun to grow hot and ferment, it will immediately be cooled by the furrounding earth. In order to keep alive that heat which is neceflary for its putrefaction, or rotting, it muft be kept in large heaps. Let any one fpread new dung over the ground, and in a week's time, if the weath- 
ex is dry, it will look little better than dry itraw; he will now find it has loft more than half its weight, and with that a large proportion of its real liches. In this ftate I have often found it in bills of potatoes in a dry feafon, where it manifenly did more hurt than good, by keeping the roots from the moilt carth: If after this it rots, yet it never can recover that which it has loft by its isch moifture being rarified and evaporated by the fun. It should therefore be fuffered to lic in fome convenient place in a body together; by which means its moifture is preferved, a fuitable degiee of heat generated, and a univerfal putrefaction takes place, turning every part of it into proper manure or food for vegetables: For in its crude ftate it can fcarcely be called a matiure, but only fomething of which a manure may be made, becaufe there is no part of it but what muft be diffolved by putrefaction before it can yield much vegetable food; hence it comes to pafs that if the feafon proves wet foon after it is ufed, it does fome good, as it affords a little nourihment by being putrified from the wetnefs of the feafon; but fnould the feafon prove dry, no putrefaction can take place, fo, that of courfe, it affords no nounifiment to vegetables, bat does real hurt by keeping the ground too open and hollow in the hills where it is put. Yard dung, then, fhould never be ufed 'till it has been in a proper fituation for fermentation and putrefaction, one year at leaft; by this means the feeds of grafs, weeds, or noxious plants. will moftly perifh, and the dung by its putrefaction, be ftored with great quantities of proper food for vegetables, poffefling thofe qualities which tend to meliorate and enrich the land. To accomplifh this plan in the fpring, it fhould be put into the place where it is intended the general compot heap flould be made. For this purpofe a hollow place thould be chofen; and if it cannot otherwife be had, it fhould be dug large enough to hold the quantity of manure intended to be made. If a place can be taken fo fituated as to receive the wafh of the divelling houfe, cow yard, hog fty, \&c. fo much the better. It muft be clayed all over its bottom and fides. Drains mun be cut from the loweft part of the cow yard, and hog $f_{y}$, into the place prepared to receive the compol, fo that what foever is wafted 
wafhed out of them by rains may be carried direcily into the compolt heap. All kinds of weeds from the fides of fields, where they often do much hurt, by fhading and drawing the nourifhment from plants that grow near them, may be pulled and thrown in : And in hoeing where the land is weedy, fmall children might of ten be cmployed to good advantage in gathering up the weeds after the hoers, and throwing them in heaps; by which they would be prevented from taking root again, the land would lie clean, and cart loads might in that way be gathered. Sprouts atfo pulled from the ftubs in new ground, when they are in a fucculent ftate, before they grow woody or hard (which by the way is the beft time to (prout new ground) may be thros $n$ in heaps and carted in : Rock weed, kelp, and all forts of fea weed or grafs, may be carried in great quantities, where they can be had ; garbage of fifh, hair, blood, bones, woolen rags, oyfter thells, mufcles, and every kind of animal fubfance, are excellent, and capable of making more than four times their own weight of good manure; ahes, fuch as are made by burning bufhes, may all be thrown in, and it is better to gather fome of the earth with them, than to leave any of the afhes, as the top of the earth in thofe places is often almoft as much impregnated with falts as the afhes themfelves; afhes that have been leeched are alfo good; the dung in the cow yard fhould be removed every morning into a heap by the fide of the yard; by this means the yard is kept clean, and the dung is kept trom drying, and as often as there is enough may be carted to the general heap. If the farmer has not the conveniency of a hog pafture, but is obliged to keep his hogs in a fty, he will find it for his intereft to throw in great quantities of green weeds, grafs, \&c. as it will fave more coftly feeding, and in this cafe the fy fhould be often cleared and its contents carried to the general heap. To a compolt heap, made of fuch nuaterials, confiderable earth may be added; but then it fhould be well chofen; any place where the wafh of a road or ftreet is brought to fettle, is excellent, and mud may often be taken from fettling plam ces in a road, and dry earth put in its place, to the great advantage both of the road and him who takes it; half a hundred loads of good loam, and even more, where there 
is a lafige yard and many cattle, may be carried into a cow-yard in the fpring of the year, and be wholly carried into the compoft heap by the fall, taking off the top at feveral different times. In Holland and fome parts of Germany, they are at great pains to fave the urine of their cattle for manure, and find it of confiderable confequence; by the above method it is all effectually preferved, which, together with the hot fteam and perfpiration of their bodies, whilf lying upon the loam, fo far enrich it as to render it a very valuable addition to the compolt heap. The compolt thould be turned up from the bottorn once or twice in a fummer, which will greatly forward its fermentation and putretaction; and towards the fall, when the feeds of weeds and grafs begin to be ripe, it is beit to move the compolt all to one end, that fuch rubbilh as abounds with ripe feeds, may be put by itfelf and lie round to another year. At the fall, when the crops come in, confiderable addition may be made by carrying in all the vines, ftalks, \&c. of every kind of vegetable from the gar den ; alfo, potatoe tops and turnip tops, if not wanted for cattle ; thefe lat make a manure of a very excellent kind. A!l the chaff from the feveral kinds of grain that may be railed-every kind of damaged or rotten ftraw or hiy, or old ftack bottoms, \&c. may come in, in the courfe of the year, with every thing that is capable of a quicis putrefaction.

Such as can afford it, will find their account in having a Thed built over their compolt heap, yet it mult be open and expofed to the air on all fides, for by fuch expofure not only the putrid fermentation will be forwarded, but much will be drawn from the air, efpecially if there be any athes in the heap, which will greatly increale the richnels of the compolt; yet a covering at the top will be very neceffary, otherwife the rains will not only greatly check the fermentation, by too often cooling it; but will probably, when they come plentifully, caufe it to overflow its banks, and carry off the rich juices of the compoft; alle, without fuch a hed it might fuftain damage by having it moft fubtle and volatile parts evaporated by the fun. I have indeed feen compolt heaps, without clay at the bottom, or a foed at the top; but, that much is loft from fuch a heap 
by all its wafhings in the courle of the year, is too manid feit to need any thing faid upon it. It is true, that in this way of putting all his nerr dung into the compolt heap. the farmer muft go a year without manure, if he has not that which is old and good by him; but when once he has his compolt heap fit for ule, after that he has his manure as regularly every year, as thole who follow the pernicious practice of wanting their new dung, (I can call it nothing better, for it often does hurt); and he who follows the above method, or fomething like it, will foon find that from one acre of land, well manured, he can raife more than he can from two without manure, fo that one half his labour will be faved; the labour and pains that he has been at in making manure, will be returned with ample increafe into his barn and ftores, and inis farm at the fame time increafing in riches.

Thole who have a good ftock of cattle, hogs, \&ic. may, in fome fuch way as the above, increafe their manure to almolt any quantity they fhall need: And fuch as have no cattle (and there are doubtlefs fome fuch among our new fettlers) may, in the above way, make confiderable manure in the courfe of the year, from the wafh of the houle only; and fuch manure is good, and will produce cucumbers, peas, beans, \&c. quicker than good yard dung. To conclude, the more any one attends to the affair of manuing his farm, the eafier and more elegantly it will fupport him ; whilf, without that, upon fuch land and in fuch a climate as we have in this country, an induftrious man may, after a courfe of years, find that all his labour hath been in vain.

Feb. 20, 1790. A FARMER。

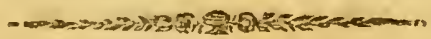

EXPERIMENTS to deiermine whether it is beft to plan: IARGE or SMALL CutTINGS of POTATOES. [By the Rev. Mr. Cochran.]

IN the Nova Scotiz Magazine* for December, 3780, there appeared fome extracts from an Efruy on Po- Vis. I. pace 454 , tatoes, 
toes, publithed among the Papers of the Bath Agricultural Society, for 1788 . In thefe a prodigious diffejence is noticed, between the produce from large cixttings and that from fmall, in favour of large ones, as nine to one.

That a confiderable difference of produce mightercape the obfervation of mere practical farmers, who fexom make comparative experiments, is readily to be fuppofec and that, therefore, it might fill be a difputed point amongt them; whether large or finall cuttings are mo?t profitable, as the author who relates thofe experiments afierts it is, and as we know it to be here. But we can hardly fuppole that any farmer, who thould fee one acre in his neighbour's field produce as much as nine in his own, would centinue inattentive to the advantage of ufing larger leed.

In the extracts, where this amazing difproportion of produce is mentioned, it is rot tated what proportion the cuttings, ufed in the one and in the other cafe, bore to each ether. Probably there was a greater difference than between thofe which are commonly ufed here. However, if the lofs by planting fmall cuttings fhould only be one half, or even one fourth part of that mentioned above, ftill it would be an object highly deferving the attention of farm. ers. I thought; therefore, it might not be a ufelefs experiment, to try two or three different fizes of cuttings, near to thofe ufually planted in this neighbourhood, and to mark the difference of produce, if any.

For this purpofe, in the fecond week of June lan, I took an equal number of cuttings, of three different fizes; the largef (No. 1:) were fomewhat larger than thofe ufually planted here. The fecond fize, which I thall call No.2, was lefs than one half of No. ${ }^{1}$. The third fize (No. 3.) was about one third of No. $2 . *$

1 planted 100 hills with each fize, four cuttings in each bill. The land, manure, and cultivation as nearly alike as I could inake then.

From

- The cunings of each fize were weighed, and the weight roted at the time of planting, but the nemurandum has been milldid. However, although $t$ cannot recollect the abfolute weight, I an certain the proportion to each oth or was, very nearly, as above. 
From the rirt appeatance of the plants, a friking difference, in favour of the largeft fize, was obfervable. Many of the hill, from No. 1, had ten, twelve, or fourteen ftalks, ftrong rid hedthy. Thole from No,2, much fewer and weak $r$. Thole from No. 3 , in many inftances had not moe than four flalks, and thofe fmali and fecble. The mifference, though ftill very perceptible, was not fo great toward the end of the fummer, as at the beginning.

In the beginning of November they were ail taken up, and the produce weighed.
No. 1, produced 280 lbs.
No. 2,
No. 3 ,
$249^{\frac{x}{x}}$
168

The medium weight of a buthel, upon feveral triale, ivas found to be 61ib. Therefore the produce of No. 1, was fomething above four buthels and a half; and the difference between No. 1, and No. 3, nearly two bufinels. This is very confiderable. If an acre planted with cuttings fuch as No 1, would produce two hundred buficls, by planting fuch as No. 3 , the farmer will toole 80 buinels. In four acres the lofs will be 320 buthels; in eighe acres, which many farmers plant in a feafon, it will be 640 bufhels!

I am informed, that fome farmers in the province plant cnly the eyes of their potaroes, and give the reft to their cattle or hogs. With thele the lofs mun be fill grcater.

[From Letrers and Papers on Agricuzizae, publifhed at HALIFAX.]

On the UTILITY of INTRODUCING the GENERAL CULTIVATION of RED CLOVER in this Province:

[By Witiliam Cottinam Tonge, Efg.]

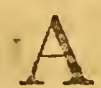

I MONGST all the late improvements in the agriculture of Great Britain, which have brought the fcience fo rear to perfection in that country, the introduction of red clover may be ranked as one of the principal and moft important; the uíe of this valuable crop, and turnips, 
turnips, has nearly banifhed the practice of employing unprofitabie fallows as a preparation for crop of grain: The tarmers of Great Britain ufe clover not ondy as the herbage for laying their lands down to meadow, byt alfo as a part of their arable fyitem; experience teacining them; that the cultivation of it, is one of the beit courfes that che be purlued for preparing land for the raifing wheat.

The introduction and general ufe of this crop, would, I am convinced, be equally beineficial to this country; to the circuinftances of which it appears every way perfectly adapted.

It is a pofition, which I conceive will be univerfally af fented to, that this province can never become rich o: flourifhing, until its inhabitants can accomplifh the raifing of therr own bread corn; and to this great object, the views of all, who wifh the profperity of the country, and particularly thofe who are employed in cultivating its lands, fhould be invariably directed.

The caufes of the prefent deficiency are not to be fought in the climate and foil of the country, but may be eafily difcovered in the injudicious and improper management of the inhabitants. The reafon that more wheat is not raifed in this province, is, that more land is not prepared for that grain; and it is a fact. well known to thofe, who are acquainted with the general practice, that much wheat is fown without any previous preparation of the land; the crops being luch as might be expected from fuch managemerit.

The complaints made againft this country, as unfavourable for wheat, are founded in ignorance or prejudice; the crops of that grain in many parts of it palpably contradict. ing fuch affertions, as does the judgment of men, who have had experience in agriculture in other countries as ivell as this. The chief real natural difavantage that the province labours under, is, the fhortnefs of the feafon for performing the feveral works of agriculiure; this circumftance may forbid the ufe of that extenlive tillage which is practifed under more favourable climates, but does by no means extend to prevent every farmer from raifing his own bread and a furplus for fale; the aggregate of which furplus will form a fund not only for the fupply of thofe who 
who are not employed in the cultivation of lands, but alfo for exporation, which I cannot relinquifh the hope of feeing trike place from this country.

As che flortnefs of our feafon may prevent us from avriling garlelves of many modes of preparing our lands, which are practifed under different climates, we fhould unqueftionably be more attentive to the ufe of thofe which are peculiarly adapted to our own; and the cultivation of clover appears to me one of the molt important of thefe, not at prefent in ule.

We cannot advantageoufly cultivate turnips (one of the great grourd works of modem hufbundry in England) to any confiderable extent, becaufe our climate will not allow of our feeding them througt the winter, and the labour of getting them up and ftoring them, would make them too expenfive; but no fuch abjection lies to the ufe of clover, which may without lofs of time, or additional expenfe (except the feed) follow our hoeing crops with the wheat, which ufually fucceeds them, and would by lying two years in the ground, prepare it in the mont perfece manner for another crop of that grain, producing in the mean time moft beneficial returns for the land it occupies. By the ufual mode of management, wheat is procured but once, after a perfect monuring with potatoes, or other hoed crops (unlefs by the execrable method of fowing it two feafons fucceffively) it being ufually followed by twa crops of oats, which diveft the foil of all its richnefs; the land is then turned out to grals, producing little or noth. ing but weeds until time has refored it to fertility, being unfit for the production of wheat, without another manuring, or laying a great length of time in pafture; whereas, by fowing clover feed with the wheat, following a hoed crop, the land is made to produce two valuable crops of hay and grafs, and is rendered in the higheft degree fit for the reception of wheat; for let the ground be in any degree rich, on which clover is fown, the deep penetrating roots and long finadowy tops of this plant are fure to increafe its richnefs, and bring it to that meliow ftate, fo favourable to the growth of that grain.

On the whole, I mott earneftly recommend to my broth. er farmers the ufe of this plant, the cultivation of which will fo much increafe the quantity of their wheat lands. 
The great obflacle to the adoption of it, is the coft of feed (if purchaled); and many have been deserred from raing it by the difficulties they have experienced in attempting to get it cleaned from the hufk; but the firft objection may be obviated by purchafing but a fmall quantity of the beft Englifh feed, for a ftock to raife more from; and the difficulty of cleanling feeci may be removed by attending to the following circumftance, which is, that in ralfing clover, to ripen feed, it is neceffary to feed down, or mow the firft growth in the fpring (which lends wholly to ftaiks, leaves and chaff), not letting it grow up till near midfummer; by this means the ftalks will be fhort and thick, will have few leaves on them, and will be covered with large heads well filled with feed, which parts cafily from the hufk.

A member of this fociety. (Mr. Burton) who firf mentioned this circumftance to me, has raifed as fine clover feed in this way as any imported from England, and will doubtlefs conmunicate to any perion, defircus of information, the methods he took to clean it,

A NEW METHOD of CULTIVATING and PREPARING

\section{Ii E M P.}

[By the ABBE BRALLE.]

Printed in England, by order of the Lords of the Committee of Council for Trade and Foreign Plantations.

\section{I} L $T$ is fufficiently known, that land intended for :
crop of hemp muft cleanfed, and gotten fine; and the feafon being a veniency of the cultivator, extending from the 25 th March to the $15^{\text {th }}$ June; fow the hemp feed, which ought ways to be new feed, thin, not exceeding two buthels to an acre, and if you have the advantage of a dilll plough, fill lefs will do. After the land is fown, go through the whole with a Chovel, and with it make litt!e paths at feven feet diftance from cach other, the length way of your piece, fo that 
that at the properfeaton you may reach the female hemp, which you will have occafion to pull out, without trampling or the male, which muft ftand at leaft a month longer to ripen its feed. The female hemp, (which is that which bears only flowers and no feed) is known to be ripe by the flowers fading, the farina foecundas falling, and fome of the ftems turning yellow. You mutt then draw out carefully the whole of the female hemp, breaking as litt'e as poffible the ftems of that which you take, or that which you leave.

Immediately as it is gathered, take it in as large hand. fuls as you can, and either cutting the roots off, or leaving them on, as you like beft (I prefer cutting them off) hold the root end uppermof, and with a wooken fword drefs off the flowers and leaves, which you leave in the field, fince they afift in manuring; pick out any weeds or fpoilt plants; put twelve handfuls, or gripes, together to make a burdic; then lay the bundles in water; it is much the beft to be running and clear water, and if thaded and overhung with trees the better; lay poles, or planks, or whatever elfe you have that is fuitable, acrols a large number logether, fo as to keep them at leaft two inches under water. Take particular notice which you lay in firft, and how you lay the bundles, in order that you may be able to. get them out again fucceflively as they were laid in, without breaking or tangling. At the end of fix days, vifit the hemp, and fee whether the reed will draw out from fome of the bundles. The time required for foaking depends very mucli on the nature of the hemp, the weather, and of the water it is foaked in-from fix days to nine, or cven to eleven. It is a trouble that is not ill beftowed to fort the hemp for forking, if it is of unequal fizes, the flendereft generally requiring molt foaking.

When you find any quantity fufficiently foaked, take it with care, putting the hards under it to prevent breakage, and tranfport it to a trough or to a table; for there are two methods of working it. If you wolk it in a trough, you muft be provicied with ote fomewhat longer than any hemp that you mean to work in it-twelve, or fourteen inches deep, and of what width you think proper according to the number of perfons you cmploy at it, as one, 
one, two, or four. To this trough muft be fitted two pieces of plank, of about a foot length, but of fuch width as to ftretch over a bundle of the hemp as it lies open in the water: Thefe planks mult be fet on one fide with teeth of brafs wire, and when the hemp is ready for draw. ing, mult be laid on it as it lies in the water, to keep it ftraight and immerged.

If you work the hemp on a table, you muf, before taking it out of the water, open a little the bundies, and rub the flems between your hands to get off what you can of the flime, and to loofen the rind. You mut likewife pufh the bundle along in the water, with the loofe end foremont, to loofen the rind at that end where the operation is to be begun. If you do not thus rub and fcour your hemp in the water where you foak it, you mult do is in the trough. But in either cafe you mult be careful to keep an even and fieady hand to avoid breaking the reed, which, as many times as it happens, renders the operation of getting the reeds out tedious. If it is wrought on the table, the bundle mut be frequently though flightly wetted. If any fuitable method could be taken to make water drip gently on it, it would be beft. A plank mult be laid on the bundle to kcep it fteady.

All matters being properly difpoled, either on the table or in the trough, you mult begin at the root end to pulth back a little of the rind from the ftem; then taking hold of one flem at a time, and rather near the outfide than the middle of the bundle, keep your hand and the reed under water (if you work in a trough) and draw it out from the bundle as ftrait as polfible, you will find it come out as clean as a fword from its frabbard. As you proceed, you may take two, afterwards four, up to fix or more reeds at a time, which will draw out ftill more eafily. When you have drawn out all the reeds that you can find at the root end, lift up the fpiked plank which was at the upper end, leaving on that which was in the middle, and draw out fuch pieces of reed as you may find at the upper end, and which have remained after drawing out what you could at the root end, becaufe they were broken. Lafly, take off the plank which lay on the middle, and take out all the relicks of recd you can perceive. If your hemp 
was in good condition for drawing, you will find all your reeds perfectly clean on the floor, and the rind, which is the hemp, lying in frait threads, in the water or on the table.

You will perceive that among the hemp there is a great quantity of gum left, looking like a jelly; this you will wah out as if you were wafhing any long itrait piece of cloth, oblerving not to difplace, or twint the threads, which would thwart the future operation of drefling, or heckling. The finer and whiter you defire the hemp to be, the more waters you will run it through, fqueezing it out at each time of wafning; but I think it always right at the laft to run it through a water in which a fmall quanity of foft foap has been beat up, after the rate of an ounce of foft loap to three pounds of the hemp when dry. Do not fqueeze it out from this foap water, but hang it to drain, and when a little fiffened, open a little the bundle, and lay it to dry on a grafs plat, or floor; the former is preferable. This foap water is not abfolutely neceffary, but is certain!y of great ufe for foftening the hemp, and rendering it pleafant and eafy to drefs; but may be difpenfed with where it is very inconvenient, and where the hemp is intended for coarfe purpofes. It is ob: vious that all thele operations would be carried on to the mol advantage near to fome running fream, or large lake, if it be a ftanding water, on account of the great ufe that is made of that element, and to fave a great deal of the trouble of tranfpurtation.

When thus dried, the hemp is proper either for drefling, or ftoring; if the latter, particular care mut be taken that it bethoroughly dry, it will otherwife heat and fpoil. As the hemp peculiarly intended to be hitherto lpoken of is the fomale, or flower bearing hemp, which is intended for fine ufes, it is to be obferved that it mult be worked with heckles, or hatchels, fuch as are ufed for flax dreffing, and may be brought to an extreme finenels; and the fhorts, having no pleces of flraw, or reed among them, may be carded and fpun, and brought into ufe for all the fame purpofes as cotton; and the fame methods ufed for bleaching and foftening. It is likewile requifite to work this hemp as foon as pulled, without which the greaten foftnels 
foftriefs and whitenefs cannot be obtained; and as this for generally falls ripe between hay time and harveft, when the weather is warm and frne, and the women moft at liberty, it will be a fuitable occafion to draw and cleanfe the hemp-the dreffing may be referved for winter.

I now proceed to fpeak of the male hemp, which being a more confiderable crop, cannot all be worked as faft as it is pulled or cut. It is known to be ripe enough by the ftems becoming pxle; for if you ftay till the tuft containing the feed appears ripe, or the ftem turns brown, the hemp will be in a great meafure fpoiled. When it is come to a proper maturity, you muit get a good number of hands, fo as to expedite the bufinefs, becaufe fuch as remains ftanding after it is ripe; will have its rind fixed to the reed, the gum turned hard and dark coloured, and the whole operation of drawing becomes difficult, troublefome, and ungrateful. The leaves are to be ftripped off with a wood. en fword, in the lame manrer as thofe of the female hemp, as are likewife the feed, the branches which grow laterally, and even the tuft bearing feed at the top : But if this latter fhould not come off clean, it mult be chopt off with an iron inftrument. All this muit be dene over a clorh, or on a fpot of ground in the field, well levelled and fmoothed, to avoid lofing any of the feed. And it is ptopofed, and faid to be fuccefsful, to leave the leed abroad; covered with the leaves and chaff Arewed on the land. This certainly faves trouble, and is practifed in many parts, but feems to me flovenly, and I would rather take it home to a barn ; but I would certainly burn all the roots, and fuch parts as are ton hard to rot eafly, and ftrew the afhes as well as the leaves, and fuch other parts as wil! eafily rot, upon the ground, as thefe matters are reckoned to go half way towards manuring the land for next year's crop. The male hemp, thus ftript of leaves and feed, will generally dry for ttoring in iweniy four hours; but at any rate mult not be left long abroad, but rather taken into theds to dry, which, when thus nript, it will fpeedily do. Sun and rain would foon fpoil it. That which can be twrought green muit be treated as before fet forth for the female hemp; and it is obvious that it is a great advantage 
to work it in this manner, rather than to dry and ftore its which caufes much trouble and expenfe and produces lels and worle hemp; but where the crop is confiderable, and the hands few, it is unavoidable. If, however, much rain comes, it is impracticable to dry it for ftoring with out fpoiling, as every year's experience fhews in the prefent received method; whereas the working the hemp green entirely avoids this difadvantage and inconveniency, and the hands engaged may continue their cmployment under the fhelter of trees, or of a temporary fhed made of a few rough poles and hurdles, covered with ftraw, reeds, \&c.

All the fame procedure is to be ufed with the male, as with the fsmale hemp, as to drawing, fcouring, \&c. but as the reeds of it are lef's brittle, and the rind coarfer, it requires more foaking, but is cafier to draw, and produces much more and ftronger hemp. What is flored muft, when wanted to be wrought, be foaked, peeled, wathed, and in general treated as before faid. In cold weather it takes long foaking.

\section{Detached Obfervations on IEemp.}

IT is capable of being cultivated on all kinds of land, the poorer land producing the hemp finer in quality, though fmaller in quantity, and the rankeft land producing ftrong and long, though coarfe; and this fort being the eafief to draw and work in the new mode, the quantity of manure requifite in the firn inftance is not above half of that for wheat, and the fubfequent years, not above half that half, and the hemp ftill improving in quality. All the work in the new method, not excepting the drefling, is fitter for women than men, and may be praetifed advantageoufly by every coltager.

No bleaching is wanted for the linen made of hemp prepared in the new method; and it is certain, that if the hemp be fine, well managed, and dreffed with the finef flax hackle, it may fuperfede almoft all the in fes of flax, which flax is a more uncertain and lefs abundant crop, requires more culture and better land, which it exhaufts; whereas hemp grounds increafe in goodnefs. If the male 
hemp intended for cords has been treated with litile attention, and but little fcoured, or bleached, the thorts which cone from it in dreffing may be fcoured over again, to render them more ufeable. The hackle, and even the bemp itfelf, may be a little oiled in the dreffing, which will much facilitate that bufinefs, and inftead ot touling, will rather affift in bleaching the threads, when they come to be wallied.

Both the dreffing and fpinning of hemp are beft carried on in a damp place. IIcmp is naturally inclined to twifl too much in fpinning.

The greatefl injury that can befal hemp, is that of fun baking. But after all, the greaten injuries that can be done to hemp, the new operation may be performed on it ; though with little fuccels, yet fufficient to render it better than that which is procured by any other operation, whereof i have, at this moment, the proof under my eye. The greateit whiteneís can never be procured but by working it green. If ftored, the greener it is got in, the whiter it will be. The more the colour is changed, the worfe will be the colour of the thread.

Fifteen pounds of male hemp may be gotten off in a day, by one perfon; only fcven pounds, of female. It is necefiary to pick the hemp plants over at feveral different periods, in order to avoid having any bad fems among the good, which might fpoil a whole parcel, efpecially if intended for fine linen.

There is great reafon, from a flight attempt that has been made, to think that a dye might be procured from the water in which the hemp is fcoured, after that it is gotien off from the reed.

It is likewife thought that an infrument may be imagined for drawing the reeds from the threads or rind, or elle the rind or threads from the reed, more expeditioufly. A few bundles have been cleaned with a common rake.

In France it is common, at the time of pulling the female hemp, to fcatter turnip feeds in among the ftems of the male liemp, which are left ftanding, and thefe turnips frequently produce a good deal of feed for theep or cactle after the male hemp is taken off. It is obvious that what 
ever has this effeet, has, befides the benefit of fupporting the flock of a farm, that of aiding to manure the hemp grounds, efpecially if it be theep that are fed on it ; therefore if this method fails, it would be prudent, immectiately as the hemp is of the ground, to plow it up, and fow turnips, cole fied, rye, or any other thing proper for theep. feed, which can be gotten off early in the next fpring, fo as to be able to till the land well in time for receiving the hemp leed.

It is lefs an injury to the hemp to pull the plarts before they are nuve enough, than to leave them too long fland. ing. It is a lels injury, in foaking the hemp, to leave it too long in the water than to take it out before it is fuff: ciently foaked.

The more the hemp is cleanfed after getting off the reed, the finer it becomes, and the finer dreffing it requires: Nothing but experience can mark the degrees.

The moft adrantageous time to begin the culture of hemp on any land, is immediately after a crop of turnips; exactly the fame as if you were about to fow barley.

The coarfent black foap, which colls in France oniy three pence per pound, wiil fuffice for making the fuds through which tise hemp ihould pars.

It is afferted, from experience, that puiting the clufters containing the hemp feeds to fweat and heat, caufes many of the feeds to come to perfection, which, in the common method, would wither and become dead; and that it of courfe improres both the quantity and quality:

'An improved METHOD of PRESERVING the FINE ILA= VOUR of BUTTER, and of PREVENTING its ... GROWING RANCID.

Communicated to the "Burlington Society for the promoting Agriculture and Domeftick "Manufactures," by their PRESIDENT, and ordered to be publifned. From the American Mifeum. Vol. VIII. Page 172:

TO a peck of fine falt add one ounce of crude fal anmoniac, and two ounces of faltpetre, both finely powder. ed : 
ed : Mix them very well with the fine falt: With this falt, work your butter, until the butter milk be entirely extracted. Then pack it in wooden firkins, falting it with the fame mixed lalt, to fuch a degree as to be palatable, when eaten with bread, and no falter. The mixture is frronger than fine falt : Of confequence fomething lefs is required,

By order of the Society,

W: COXE, JUN. SEC'RY.

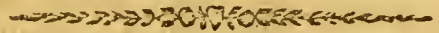

Drnzomons for the MANUFACTURING SU.G AR from the Marie Tree.

[Fum the Americam Museuno]

If the fap is drawn into wooden veffels, care fhould be taken that they are made of fuch wood as will not give the liquor a bad tafte. Some maple figar has a difagreeable tafte, occafioned, as I have been informed, by the fap having been put into trays made of the white walnut. If the moulds are made of wood, they alfo thould be made of fome lind of tree that will give no tafte. The greateft part of the maple fugar I have feen, has too fmall a grain; which is owing to two caufes; one is, the makers of it do not ufe lime or lye, or any thing elfe, to make it granulatc; the other is, that they boil the fugar too much. - The quantity of lime neceifary to anfwer the purpofe, I cannot exactly afcertain ; but I fuppofe, a heaped fpoonful of flacked lime would be fufficient for about fix gallons of fap. A judicious perfon after a few trials, would be able to fix the due proportion. It may, however, be proper to mention, that if the quantity of lime is too fmall, the fugar will not be fufficiently grained; if too much, it will give the fugar a reddin caft. I have before oblerved, that the fugar fhould not be boiled fo much as has been the common practice. That, from which runs about one fixth of its weight in melaffes, in twenty four hours after it is put to drain, I think, has been boiled properly; perhaps, in three 
three or four weeks aficrwards, it will run the like guanti ty of melalfes, making the whole of the sunning about one thind the meint of the green lugar. It is probable that thole who have betn accuntomed to high boiling, in order to get as much fugar as pofible in the firft procels, will not apwiove of this method, bill perhaps may be better reconcicd to it, when they are informed, that if they boil this melafes or fytup with frong lime water, one third of the latter to two thirds of the melalles, there is reafon to expece it will make good fugar, although not cqual to the finfle fort.

If fall now proceed to give fome directions for the making of mapic fugar :--.- Let all the fap that has becn colleded in one day, be boiked the day following, lef it. Thould fer. ment, in which cafe the fugar would be lefs in quantity, and worfe in cuality. To carry on the bufinefs to the greatelt advantage; there fhould be three kettles of different cimenfions. Thefe kettles flould be fixed in a row, the frulleft at one cnd, the middle fized next, and the largen at the other end. - TWhen there is a quantity of fap colleded, put as much in the largeh ketile as can be converienty bciled in it; then throw in as wich lime or lye as may be deemed neceffary to make the liquor granulate. Keep a moderatc fire for fome time, and as the fcum rifes, take it of with a frimmer ; after the liquor is pretty. clear, incieale the fire and boil it brifki', 'till fo much is craporatcd, as that which remains may be boiled in the middle ketle; into which the liguor min be Itrained through a blanket; under this lettle, keep a grood fire, and take off the foum as it rifes." As foon as the licuor is taken from the large, and put into the mialle kettle, frefh fap muft be put into the former, and treated as beforc directed, and fo on, till all the fap is boiled.

When the liquor is fuficiently evaporated in the mid. Ile kettle, to admit its being boiled in the fmalleft, it nuff be put into the laft, where it mult be boiled, until it gets to a proper confiftency to make fugar. When the liquor is saken from the middle kettie into the frallef, the former muft be fupplied, as is before directed, from the largent with

* Some liquor mould be left in the large kettie, if an iron one, otherxife there would be a danger of its foliting, unon putting in cold liquor. 
With freth fap. The liquor, in the fmall kettle; muft be boiled brifkly, until it gets pretty thick, when the fire thould be leffened, to prevent its burning. When the liquor rifes in the kettle, a piece of butter or fat, the fize of a hazle nut, may be thrown in ; if this quantity does not make it boil flat, more fhould be added, until it anfwers the purpofe, and this mult be repeated as often as the liquor rifes. When it is boiled enough, which may be known by the mannert of its roping between the thumb and finger, it muft be put into a cooler or tub, when the fmall kettle mult be fupplied, with liquor from the middle fized one, that, with more from the largeft, and the large one with frefh lap, as is beforedirected. When one third of the fap, that has been co!lected, is boiled and put into the cooler, it mult be flirred brifkly about with a ftirring ftick (which may be made like a fmall paddle) until it grains, when it may be left (if the bufinefs has been well done) until another third of the liquor is boiled, and put into the cooler : It muft be then moved about with the ftirring ftick, until it is well mixed together-when the remainder of the liquor is boiled and put into the cooler, it muft again be moved about with the flirring fick, until the whole is well mixed, when it muft be put into moulds; earthen would be beft; but wooden moulds may be made to anfwer the purpofe, by nailing or pinning four boards together, fo fhaped as to make the mould one inch diameter at the bottom, and ten or twelve inches at the top; the length may be two feet, or two feet and an half-thefe moulds muft be clofely ftopped at the fmall ends, with old coarfe linen, or fome fuch thing, and fet up with fomething to flay them; the fugar muft then be taken from the cooler, and poured into the moulds-next morning the floppers muf be taken out, and the moulds be put on troughs, or fome veffel to drain their melaffes. In the evening, the loaves muft be pierced at the fmail ends, to make them run their fyrup freely - this may be done by driving a wooden pin, (fhaped like a marling fpike) three or four inches up the loaf; after which they munt be left

+ Dip a fick into the liquor, apply the thumb to it, and take part of what adheres to the ftick, then draw it two or three times between the thumb and fingrer, 
to drain their melafies, which will be done in a fuortex or longer time, according as the fugar has been boiled.

No part of the bufinefs requires greater attention thar granulating or graining the fugar in the cooler, and afterwards frequently obferving the Aate it is in-if too thick, it may be remedied by boiling the remaining liquor lower, than that which was boiled before-if too thin, by ftirring the cooler again, and boiling the remainder of the liquor higher, or more.

Philadelphia, Auguft 21, 1789.

A SUGAR BOILER.

The making of fugar is quite common and eafy with a fingle kettie of any fize. 





